\title{
Ardahan ve Elazığ illerinde Yetişen Anchusa azurea Miller var. Azurea Bitkisinin Biyoaktif Bileşenleri ve Antioksidan Kapasitesi Üzerine Bir Araştırma
}

\author{
Zehra Tuğba MURATHAN ${ }^{\varnothing}$ (D) Musa ÖZDINÇC (D) \\ Ardahan Üniversitesi, Mühendislik Fakültesi, Gıda Mühendisliği Bölümü, \\ $\bowtie:$ ztugbaabaci@hotmail.com
}

\section{ÖZET}

Bu çalışmada, Ardahan ve Elazığ illerinden toplanan Anchusa azurea Miller var. Azurea bitkisinin yapraklarında askorbik asit, toplam fenolik madde, toplam flavonoid madde ve pigment içerikleri ile antioksidan kapasite analizleri gerçekleştirilmiştir. Ardahan ilinden toplanan Anchusa azurea var. Azurea bitkisinin yapraklarında askorbik asit, toplam fenolik madde ve toplam flavonoid madde miktarlarının Elazığ ilinden alınan örneklere oranla daha düşük bulunmuştur. Elazığ ilinden toplanan örneklerde askorbik asit, toplam fenolik madde ve toplam flavonoid madde miktarlarının sirasıyla $72.9 \mathrm{mg} / 100 \mathrm{~g}, 302.1 \mathrm{mg} / 100 \mathrm{~g}$ ve $99.67 \mathrm{mg} / 100 \mathrm{~g}$ olduğu tespit edilmiştir. Ardahan ilinden toplanan örneklerde ABTS (2,2-Azino-bis3-etilbenzotiyazolin-6-sülfonik asit), DPPH (2,2-difenil-1-pikrilhidrazil-hidrat), ve FRAP (Demir iyonu indirgeyici antioksidan güç) sonuçlarının sırası ile \%76.1, \%89.3 ve $1386.1 \mu \mathrm{mol} \mathrm{Fe} \mathrm{II/g} \mathrm{olduğu}$ belirlenmiştir. Farklı ekolojik koşullarda yetişen örneklerin pigment içeriği sonuçlarının da değişkenlik gösterdiği tespit edilmiştir.
DOI :10.18016/ksudobil.362296

Makale Tarihçesi

Geliş : 05.12.2017

Kabul : 20.02.2018

\section{Anahtar Kelimeler}

Anchusa azurea Miller var.

Azurea, antioksidan,

fenolik,

flavonoid

\section{Araştırma Makalesi}

A Research on Bioactive Compounds and Antioxidant Capacities of Anchusa azurea Miller var. Azurea Plant Grown in Ardahan and Elazığ Cities

\begin{abstract}
In this study, total phenolic contents, total flavonoid contents, total ascorbic acid contents and antioxidant capacities of the samples of Anchusa azurea Miller var. Azurea growing in Ardahan and Elazığ cities were determined. The total ascorbic acid, total phenolic and total flavonoid content, was found to be the lowest in Elazığ azurea leaf samples than those of Ardahan. It has been determined that the total ascorbic acid, total phenolic and total flavonoid content of Elazığ samples sustained $72.9 \mathrm{mg} / 100 \mathrm{~g}, 302.1 \mathrm{mg} / 100 \mathrm{~g}$ ve $99.67 \mathrm{mg} / 100 \mathrm{~g}$, respectively. In the samples taken from the Ardahan, ABTS $\left(2,2^{-}\right.$ Azino-bis-3-ethylbenzothiazoline-6-sulfonic Acid), DPPH (2,2diphenyl-1-picryl-hydrazyl-hydrate) and FRAP (Ferric Reducing Antioxidant Power) values were found higher than the other samples. The ABTS, DPPH and FRAP of Ardahan samples were 76.1\%, 89.3\% and $1386.1 \mu \mathrm{mol} \mathrm{Fe} \mathrm{II/g,} \mathrm{respectively.} \mathrm{The} \mathrm{pigment} \mathrm{contents} \mathrm{of} \mathrm{the}$ samples grown in different ecological conditions were varied in the study.
\end{abstract}

\author{
Article History
}

Received : 05.12.2017

Accepted : 20.02. 2018

To Cite : Murathan ZT, Özdinç M 2018. Ardahan ve Elazı̆̆ illerinde Yetişen Anchusa azurea Miller var. Azurea Bitkisinin Biyoaktif Bileşenleri ve Antioksidan Kapasitesi Üzerine Bir Araştırma. KSU J. Agric Nat 21(4):529-534, DOI:10.18016/ksudobil.362296.

\section{Gİiş̧}

İlk çağlardan kalan arkeolojik bulgulara göre insanlar, besin elde etmek ve sağlık sorunlarını gidermek amacıyla öncelikle bitkilerden faydalanmışlardır (Cotton, 1996; Koçyiğit, 2005). Özellikle Anadolu insanı bitkileri, gıda ve tıbbi amaç için kullanmıştır
(Güner ve ark., 2000). Ülkemizde yapraklarından veya köklerinden yemek yapılan birçok bitki türü mevcuttur. Bu bitkilerden bir tanesi de halk arasinda tort olarak bilinen Anchusa azurea Miller var. Azurea bitkisidir. Bu bitki ülkemizde Tekirdağ'dan Ardahan'a kadar birçok bölgede yetişmektedir (Anonim, 2017). 
Farklı bölgelerde ballık otu ve sığırdili olarak da bilinmektedir (Deniz ve ark., 2011).

Anchusa azurea Miller var. Azurea bitkisinin yaprakları ülkemizde birçok bölgede sebze olarak tüketilmektedir. Bitkinin yaprakları özellikle ilkbahar ve yaz aylarında haşlanıp soğanla kavrularak yemek olarak tüketilmekte, börek ve diğer hamur işlerinin içinde kullanılmaktadır. Bitkinin kökü kaynatılarak kırmızı, kuru toprak üstü kısımlarından mavi boya elde edilmektedir. Kökün kabuğu buğday ile birlikte öğüülüp, iltihaplı yaraların tedavisinde kullanılmaktadır. Yabani bitki zehirlenmelerine karşı faydası vardır. Ciltteki çatlaklarda, egzama hastalığinda kökleri tuz ile ezilip sorunlu bölgeye sarılarak kullanılmaktadır (Ertuğ, 2004; Çöteli, 2015). Yaprak ve çiçekli dalları terletici, idrar arttırıcı ve ülser tedavi edici olarak dekoksiyon veya infüzyon halinde kullanılmaktadır (Çakılcıŏlu ve ark., 2007). Bununla birlikte bitki, hayvan yemi olarak da kullanılmaktadır (Gelse, 2012). Bölgelere göre kullanım şekli değişiklik göstermektedir. Şeker hastalığına iyi geldiği, iltihaplanma, mide ağrısı, sindirim rahatsızlıkları, romatizmaya karşı kullanıldığı, yara ve kesik tedavisinde etkili olduğu bildirilmiştir (Polat ve Satıl, 2012; Arı, 2014).

$\mathrm{Bu}$ çalışmada halk arasında yemek yapımında kullanılan, ekolojik özellikleri farklı iki bölgede yetişen Anchusa azurea Miller var. Azurea bitkisi yapraklarının bazı biyoaktif madde içerikleri ile antioksidan kapasitelerinin karşılaştırılması amaçlanmıştır. $\mathrm{Bu}$ amaçla materyallerin toplam fenolik madde, toplam flavonoid madde, askorbik asit ve pigment içerikleri ile antioksidan kapasiteleri belirlenmiştir.

\section{MATERYAL ve METOT}

\section{Bitki Materyali}

Çalışmada kullanılan Anchusa azurea Miller var. Azurea bitkilerine ait örnekler Ardahan (1900 m) ve Elazığ $(1015 \mathrm{~m})$ illerinden toplanmıştır. Örneklerin sistematik teşhisleri Flora of Turkey and The East Aegean Island'a göre yapılmıştır (Davis, 1970). Bitkilere ait yaprak örnekleri bitkinin çiçek açmadan önceki dönemi olan ve en fazla tüketildiği Haziran ayında toplanarak polietilen torbalar içerisinde laboratuara getirilmiş ve kullanılıncaya kadar - 80 ${ }^{\circ} \mathrm{C}$ 'de bekletilmiştir.

\section{Ekstrakt Hazırlanması}

$2 \mathrm{~g}$ bitki örneği $20 \mathrm{ml}$ metanol (\% 80) ile Ultra-Turrax ile homojenize (WiseTis ${ }^{\circledR}$ homogenizer, HG 15A) edilmiş ve 24 saat dairesel çalkalamalı etüvde (ACMI 006), $5{ }^{\circ}$ C'de bekletilmiştir. Daha sonra $10 \mathrm{dk} 5000$ rpm'de santrifüj edilmiştir. Alınan süpernatan toplam fenolik madde, toplam flavonoid madde ve antioksidan kapasite analizlerinde kullanılmıştır. Askorbik asit tayini için çözücü olarak okzalik asit (\%0.4) kullanılmıştır.

\section{Toplam Fenolik Madde Tayini}

Toplam fenolik madde tayini Folin-Ciocalteu yöntemi kullanılarak belirlenmiştir (Spanos ve Wrolstad, 1992). $200 \mu \mathrm{l}$ ekstrakt üzerine $1000 \mu \mathrm{l}$ Folin-Ciocalteu ve $800 \mu \mathrm{l}\left(\%\right.$ 7.5) $\mathrm{Na}_{2} \mathrm{CO}_{3}$ eklenmiştir. Oda sicaklığında 2 saat inkübasyona birakıldıktan sonra, spektrofotometrede (Unico, S1205) 765 nm'de ölçülmüştür. Örneklerin toplam fenolik madde içerikleri gallik asit standardı kullanılarak mg/100 g cinsinden hesaplanmıştır.

\section{Toplam Flavonoid Madde Tayini}

Toplam flavonoid madde tayini Quettier ve ark. (2000)'nın geliştirmiş oldukları yönteme göre belirlenmiştir. $1 \mathrm{ml}$ ekstrakt üzerine $1 \mathrm{ml} \% 2$ 'lik $\mathrm{AlCl}_{3}$ eklenerek oda sicaklığında ve karanlıkta 1 saat bekletilmiştir. Örneklerin toplam flavonoid madde miktarları $415 \mathrm{~nm}$ dalga boyunda spektrofotometre ile ölçülmüş ve (+)- epikateşin kullanılarak hazırlanmış olan kalibrasyon eğrisinden yararlanılarak mg/100 g cinsinden hesaplanmıştır.

\section{Askorbik Asit Tayini}

Askorbik asit tayini spektrofotometrik olarak belirlenmiştir (AOAC, 1990). $100 \mu \mathrm{ll}$ süpernatant üzerine $400 \mu \mathrm{L} \% 0.4$ 'lük okzalik asit ve $4.5 \mathrm{ml} \mathrm{2,6-}$ diklorofenolindofenol çözeltisi eklenmiş ve absorbans değerleri 520 nm'de spektrofotometrik olarak belirlenmiştir. Örneklerdeki askorbik asit miktarı saf askorbik asitle çizilen kalibrasyon eğrisi yardımıyla $\mathrm{mg} / 100 \mathrm{~g}$ cinsinden hesaplanmıştır.

\section{Antioksidan Kapasite Tayini}

Örneklerin antioksidan kapasiteleri DPPH (2,2difenil-1-pikril-hidrazil-hidrat), ABTS (2,2-Azino-bis3-etilbenzotiyazolin-6-sülfonik asit) ve FRAP (Demir iyonu indirgeyici antioksidan güç) yöntemleri kullanılarak belirlenmiştir.

\section{DPPH Serbest Radikali Süpürücü Aktivite}

$4 \mathrm{ml}$ DPPH solüsyonu (0.1 M) $1 \mathrm{ml}$ ekstrakt ile birleştirilerek, $30 \mathrm{dk}$ karanlık bir ortamda, oda sıcaklığında, çalkalayıcıda bekletilmiştir. Spektrofotometrede $515 \mathrm{~nm}$ dalga boyunda absorbans ölçümleri yapılmıştır. Antioksidan kapasite $\% \mathrm{DPPH}=\left(\mathrm{A}_{\text {kontrol }} \mathrm{A}_{\text {örnek }}\right) / \mathrm{A}_{\text {kontrol }} \mathrm{x} 100$ formülüyle hesaplanmıştır (Rezaeirad vd., 2013).

\section{ABTS Serbest Radikali Süpürücü Aktivite}

ABTS yöntemi Re ve ark. (1999)'na göre yapılmıştır. 7 $\mathrm{mM}$ ABTS ve $2.45 \mathrm{mM}$ potasyum per sülfat ile $1: 1$ oranında stok solüsyon hazırlanmış ve 16 saat oda sıcaklığında karanlık ortamda inkübe edilmiştir. Analizler için stok solüsyon absorbansı $734 \mathrm{~nm}$ 'de $0.7 \pm 0.05$ olana kadar etanolle seyreltilmiştir. $150 \mu \mathrm{l}$ örnek $2.85 \mathrm{ml}$ ABTS solüsyonuyla karıştırılmış ve $6 \mathrm{dk}$ oda sicaklığında inkübe edildikten sonra $734 \mathrm{~nm}$ 'de 
absorbansı ölçülmüştür. Antioksidan kapasite $\%$ ABTS $=\left(\mathrm{A}_{\text {kontrol}}{ }^{-} \mathrm{A}_{\text {örnek }}\right) / \mathrm{A}_{\text {kontrol }}$ x 100 formülüyle hesaplanmıştır.

\section{Demir iyonu indirgeyici antioksidan güç (FRAP)}

FRAP yöntemi Benzie ve Strain (1996)'e göre yapılmıştır. FRAP çözeltisi $25 \mathrm{ml}$ sodyum asetat tamponu (300 mM, pH3.6), $2.5 \mathrm{ml}$ TPZT solüsyonu (10

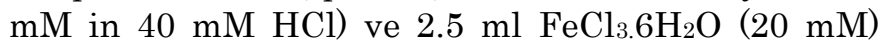
karışımıyla hazırlanmıştır. Çözelti $37{ }^{\circ} \mathrm{C}$ 'de su banyosunda ılıtılmış ve $900 \mu$ l'si bir küvete alınarak başlangıç absorbans değeri okunmuştur. Seyreltilmiş (1:4 v/v su) örneğin $100 \mu l$ 'si küvete alınmış ve üzerine $3 \mathrm{ml}$ FRAP çözeltisi eklenmiştir. $4 \mathrm{dk}$ sonra absorbans 593 nm'de ölçülmüştür. Satandart eğri $\mathrm{FeSO}_{4}$ solüsyonu kullanılarak hazırlanmıştır (100-1000 $\mu \mathrm{l})$. Sonuçlar $\mu \mathrm{mol} \mathrm{Fe}$ (II)/g cinsinden hesaplanmıştır.

\section{Pigment Analizleri}

Pigment analizleri De-Kok ve Graham (1980)'a göre yapılmıştır. $1 \mathrm{~g}$ yaprak örneği $50 \mathrm{ml}$ aseton ile homojenize edilmiş ve karanlıkta $30 \mathrm{dk}$ çalkalamalı etüvde bekletilmiştir. Daha sonra 24 saat buzdolabında bekletilmiştir. Filtre edilen örneğin beşte biri kadar distile su ilave edilmiştir. $15 \mathrm{dk}$ çalkalamalı etüvde (ACMI 006) $25{ }^{\circ} \mathrm{C}$ 'de bekletilmiş ve 3000 rpm'de $10 \mathrm{dk}$ santrüfüj edilmiştir. Daha sonra 470, 645 ve 662 nm'de absorbansları saptanmıştır. Sonuçlar formüllerde belirtildiği gibi hesaplanmıştır.
Klorofil a: $11.75 * \mathrm{~A} 662-2.35 * \mathrm{~A} 662$

Klorofil b: $18.61 * A 645-3.96 * \mathrm{~A} 662$

Toplam Karotenoid: (1000*A470-2.27*Klorofil a$81.4 *$ Klorofil b)/227

Toplam klorofil: Kla+Klb

\section{İstatistiksel Analizler}

Çalışmada her bölge için üç farklı örnekte analiz yapılmış ve ortalama değerleri alınmıştır. Örneklerin ortalama değerleri ve standart sapmaları SPSS 16.0 paket programı aracılığ Ortalamalar arasındaki farklılıklar t-testi ile belirlenmiştir $(\mathrm{p}<0.05)$.

\section{BULGULAR ve TARTIŞMA}

Fenolik bileşikler fiziksel ve biyolojik strese karşı oldukça büyük bir öneme sahiptir. Bunun dışında tat ve renk gibi meyvenin kalitesini ortaya koyan farmakolojik karakteristiklerin ve faktörlerin oluşmasında da rol oynamaktadırlar (Macheix ve ark., 1990). Yaptığımız çalışmada en yüksek toplam fenolik madde, toplam flavonoid madde ve askorbik asit miktarları Elazığ ilinden toplanan örnekte, en düşük değerler ise Ardahan ilinden toplanan örnekte belirlenmiştir. Toplam fenolik madde miktarı, toplam flavonoid madde miktarı ve askorbik asit miktarı Elazığ ilinden alınan bitki örneklerinde sırasıyla 302.1 $\mathrm{mg} / 100 \mathrm{~g}, 99.67 \mathrm{mg} / 100 \mathrm{~g}$ ve $72.9 \mathrm{mg} / 100 \mathrm{~g}$ olarak bulunmuştur (Tablo 1 ).

Tablo 1. Anchusa azurea Miller var. Azurea Örneklerinin Bazı Biyoaktif Bileşenleri

\begin{tabular}{|l|c|c|c|}
\hline & $\begin{array}{c}\text { Toplam Fenolik Madde } \\
\text { Miktarı }(\mathrm{mg} / 100 \mathrm{~g})\end{array}$ & $\begin{array}{c}\text { Toplam Flavonoid Madde } \\
\text { Miktarı }(\mathrm{mg} / \mathbf{1 0 0 g})\end{array}$ & $\begin{array}{c}\text { Askorbik asit Miktarı } \\
(\mathrm{mg} / \mathbf{1 0 0 g})\end{array}$ \\
\hline Elazı̆ & $302.1 \pm 22.1^{\mathrm{a}}$ & $96.67 \pm 5.2^{\mathrm{a}}$ & $72.9 \pm 3.6^{\mathrm{a}}$ \\
\hline Ardahan & $232.7 \pm 32.6^{\mathrm{b}}$ & $86.39 \pm 5.6^{\mathrm{b}}$ & $59.1 \pm 6.2^{\mathrm{b}}$ \\
\hline
\end{tabular}

Her sütunda farklı harfle gösterilen rakamlar istatistiksel olarak birbirinden farklıdır $(\mathrm{p}<0.05) \mathrm{n}=3$

Yüksek rakımlı bölgelerde yetişen bitkilerin vejetasyon süresi daha uzun olmaktadır. Bazı araştırıcılar bu durumun daha fazla fenolik madde birikimine neden olduğunu düşünmektedir (Rieger, 2007). Daha önce yapılan bazı çalışmalarda yüksek rakımlı bölgelerde yetişen bitkilerin ve meyvelerinin daha yüksek fenolik madde içeriğine sahip olduğu bildirilmiştir (Martz ve ark., 2010; Korkutal ve ark., 2012; Murathan, 2017). Li ve ark. (2017) ise tam tersine düşük rakımlarda yetişen Podophyllum hexandrum meyvelerinde fenolik madde içeriğinin daha yüksek olduğunu tespit etmişlerdir. Çalışmamızda Elazığ ilinde yetişen bitkilerin yapraklarında biyoaktif bileşenlerin miktarı daha yüksek bulunmuştur.

A.azurea Miller var. Azurea bitkisinde biyoaktif bileşenlerin miktarı ve antioksidan kapasiteyi belirlemek amacıyla yapılmış çok fazla çalışma bulunmamaktadir.

Daha önce yapılan bir çalışmada A.azurea bitki ekstraktlarında askorbik asit miktarı $30.88 \mu \mathrm{g} / \mathrm{g}$ olarak bildirilmiştir (Çöteli, 2015). Morales ve ark. (2014) A.azurea bitkisi metil alkol ekstraktlarında askorbik asit miktarını $0.67 \mathrm{~g} / 100 \mathrm{~g}$ olarak, toplam fenolik madde miktarını $148.62 \mathrm{mg}$ GAE/g ve toplam flavonoid madde miktarını $84.81 \mathrm{mg}$ GAE/g olarak bulmuşlardır. Bitkinin köklerinin de yaprakları gibi çok fazla fenolik bileşen içerdiği rapor edilmiştir (Kuruüzüm־uz ve ark., 2013). Conforti ve ark. (2011) yaptıkları çalışmada A.azurea bitkisinde toplam fenolik madde miktarını $85.5 \mathrm{mg} / \mathrm{g}$ olarak bulmuşlardır. Zengin ve ark. (2015) A.undulata L. subsp. Hybrida bitkisinde yaptıkları çalışmada toplam fenolik madde miktarını $80.34 \mathrm{\mu g}$ GAE/mg, toplam flavonoid madde miktarinı $25.09 \mu \mathrm{g}$ QEs/mg olarak belirtmişlerdir. Boussoualim ve ark. (2014) bitkide flovanoid madde miktarını $1.88 \mathrm{mg} / \mathrm{g}$ olarak belirtmisslerdir. Yine Marelli ve ark. (2015) bitkide toplam flavonoid madde miktarmı $0.9 \mathrm{mg} / \mathrm{g}$ olarak bildirmişlerdir. Daha önce yapılan çalışmalardaki sonuçların bazıları bizim çalışmamızda elde ettiğimiz sonuçlara göre yüksek (Conforti ve ark., 2011; Morales 
ve ark., 2014; Zengin ve ark., 2015) bazıları ise düşüktür (Çöteli, 2015; Boussoualim ve ark., 2014; Marelli ve ark., 2015). Bu durum bitkinin yetiştiği bölgenin toprak ve ekolojik yapısına, kullanılan analiz yöntemine, çözücüye ve ekstraksiyon koşullarına bağlı olabilmektedir.

Klorofil pigmenti bitkilerde birçok fizyolojik fonksiyonu düzenlemektedir. Özellikle bitkinin strese girdiği durumlarda klorofil miktarlarında önemli değişimler meydana gelmektedir. Bitkilerde en fazla klorofil a ve b pigmentleri bulunmakta, genel olarak bitkiler klorofil a (sarı־yeşil) ve b (mavi-yeşil) pigmentlerini $\quad 3: 1 \quad$ oranında içermektedirler (Cemeroğlu ve ark., 2001). Klorofil ve karotenoid gibi pigmentler antioksidan potansiyele sahiptirler (Gökpınar, 2006). Karotenoidler yeşil bitkilerde, sarı ve turuncu renkli meyve ve sebzelerde yoğun olarak bulunan pigmentlerdir. Çeşitli tipleri mevcuttur ancak en iyi bilineni A vitamini öncül maddesi olan Bkarotendir. A.azurea Miller var. Azurea bitkisi örneklerinin pigment içeriği (klorofil a, klorofil b, toplam klorofil ve karoten miktarları) sonuçları Tablo 2'de görülmektedir. Farklı iki bölgeden temin edilen örneklerde pigment içeriği bakımından önemli istatistiksel farklılıklar saptanmıştır. Her iki örnekte de klorofil a içeriğinin klorofil b içeriğinden daha yüksek olduğu tespit edilmiştir. Klorofil a değerlerinin $12.42 \mu \mathrm{g} / \mathrm{g}$ ile $13.87 \mu \mathrm{g} / \mathrm{g}$, klorofil b değerlerinin 4.49 $\mu \mathrm{g} / \mathrm{g}$ ile $5.47 \mu \mathrm{g} / \mathrm{g}$, toplam klorofil değerlerinin 16.92 $\mu \mathrm{g} / \mathrm{g}$ ile $19.33 \mu \mathrm{g} / \mathrm{g}$ ve toplam karotenoid değerlerinin ise $3.86 \mu \mathrm{g} / \mathrm{g}$ ile $3.96 \mu \mathrm{g} / \mathrm{g}$ olduğu belirlenmiştir. Ardahan bölgesinden alınan örneklerin klorofil b miktarlarının Elazığ ilinden toplanan örneklere oranla daha yüksek olduğu tespit edilmiştir. Klorofil a, toplam klorofil ve toplam karotenoid içeriklerinde ise illere göre istatistiksel anlamda önemli farklılıklar tespit edilememiştir. Rakım artışı ile artan UV ışınlarının bitkilerde koruyucu pigment sentezinin artmasına ve yoğun renklenmelere neden olduğu bildirilmiştir (Aslantaş ve Karabulut, 2007). Çalışmamızda Ardahan bölgesinden alınan örneklerde pigment yoğunluğunun daha fazla olması bu bulguyu desteklemektedir.

Tort bitkisinin pigment içerikleri daha önceki çalışmalarda belirlenmemiştir. Yiyecek olarak kullanılan bazı bitkilerin pigment içerikleri aşağıda verilmiştir. Zilic ve ark. (2016) Mentha piperita (nane) bitkisinde klorofil a miktarının $774.1 \mathrm{mg} / 100 \mathrm{~g}$, klorofil b miktarının $356.8 \mathrm{mg} / 100 \mathrm{~g}$ olduğunu bildirmişlerdir. Loranty ve ark. (2010) Urtica dioica (1sirgan) yapraklarındaki klorofil a miktarını $58.7 \mathrm{mg} / \mathrm{g}$ olarak tespit etmişlerdir. $\mathrm{Bu}$ değerlerdeki farklılıklar tür farklılığ ve rakım gibi değişkenlerden kaynaklanabilmektedir. İnsan vücudunda çevresel kirlilik, UV ışınları, toksik kimyasallar, sigara, alkol kullanımı gibi nedenlerle oluşan serbest radikaller, hücrelerin membran lipidlerini, DNA'sinı ve proteinlerini potansiyel hedef olarak görmekte ve bu moleküllere zarar vererek kanser, damar sertleşmesi, iltihabi hastalıklar, yaşlanma, kalp hastalıkları, cilt hastalıkları, diyabet, Parkinson, alzheimer gibi birçok hastalığı ortaya çıkarmaktadır (Halliwell, 2000). Serbest radikallerin organizmada aşırı artışı oksidatif stres adı verilen durumu ortaya çıkarmaktadır.

Dünya sağlık örgütü (WHO), oksidatif stresin neden olduğu zararlı etkileri ortadan kaldırmak amacıyla doğal ürünlerin tüketimini önermektedir (Murthy ve ark., 2004). Daha önceki çalışmalar bitkisel ürün tüketiminin kanser, diyabet, kardiyovasküler hastalıklar ve sinir hastalıkları gibi kronik hastalıklara yakalanma riskini azalttı̆̆ını göstermektedir (Gorinstein ve ark., 2002). Bu durum bitkilerde bulunan fenolik bileşiklerin, pigmentlerin ve vitaminlerin antioksidan etkisinden kaynaklanmaktadır (Galvis-Sa'nchez ve ark., 2003). Bitkilerin antioksidan kapasitelerini belirlerken en uygun metodu seçmek önemlidir. Bu çalışmada üç farklı metot (DPPH, FRAP ve ABTS) kullanılmıştır. DPPH metodunun temeli bitki ekstraktındaki antioksidanların DPPH radikalini süpürme yüzdesine dayanmaktadır. FRAP metodunda temeli antioksidan maddeler içeren bir örneğin oksidan özellikte olan ferik formdaki demiri ferro formuna indirgeme gücüne dayanır. ABTS metodunun temeli ise bitki ekstraktındaki antioksidanların ABTS radikalini süpürme yüzdesine dayanmaktadır (Parejo ve ark., 2000; Mbaebie ve ark., 2012). Bitkilerin ABTS, FRAP ve DPPH yöntemleri ile belirlenen antioksidan kapasite değerleri Tablo 3’te verilmiştir.

Tablo 2. Anchusa azurea Miller var. Azurea Örneklerinin Pigment İçerikleri

\begin{tabular}{|l|c|c|c|c|}
\hline & Klorofil a $(\mu \mathrm{g} / \mathbf{g})$ & Klorofil b $(\mu \mathrm{g} / \mathrm{g})$ & Toplam klorofil $(\mu \mathrm{g} / \mathrm{g})$ & Toplam Karotenoid $(\mu \mathrm{g} / \mathrm{g})$ \\
\hline Elazı̆ & $12.42 \pm 1.2$ & $4.49 \pm 0.9^{\mathrm{b}}$ & $16.91 \pm 1.1$ & $3.86 \pm 0.09$ \\
\hline Ardahan & $13.865 \pm 1.5$ & $5.47 \pm 0.03^{\mathrm{a}}$ & $19.34 \pm 0.8$ & $3.96 \pm 0.04$ \\
\hline
\end{tabular}

Her sütunda farklı harfle gösterilen rakamlar istatistiksel olarak birbirinden farklıdır $(\mathrm{p}<0.05) \mathrm{n}=3$

Tablo 3. Anchusa azurea Miller var. Azurea Örneklerinin Antioksidan Kapasite Değerleri

\begin{tabular}{|l|c|c|c|}
\hline & ABTS (\%) & FRAP $(\mu \mathrm{mol} \mathrm{Fe} \mathrm{II/g)}$ & DPPH (\%) \\
\hline Elazı̆g & $72.1 \pm 9.6$ & $1331.5 \pm 109.6$ & $61.7 \pm 8.1^{\mathrm{b}}$ \\
\hline Ardahan & $76.1 \pm 6.4$ & $1386.1 \pm 185.7$ & $89.3 \pm 7.9^{\mathrm{a}}$ \\
\hline
\end{tabular}
Her sütunda farklı harfle gösterilen rakamlar istatistiksel olarak birbirinden farklıdır $(\mathrm{p}<0.05) \mathrm{n}=3$


Biyoaktif bileşenlerin aksine Ardahan ilinden toplanan bitki örneklerinde DPPH radikali süpürücü aktivite daha yüksek olarak belirlenmiştir. Elazığ ilinden alınan bitki ekstraktlarında ABTS radikali süpürücü aktivite $\% 72.1$, DPPH radikali süpürücü aktivite \%61.7 ve demir iyonu indirgeyici antioksidan güç (FRAP) değeri ise $1331.5 \mu \mathrm{mol} \mathrm{Fe} \mathrm{II/g}$ iken Ardahan ilinden alınan bitki ekstraktlarında bu değerler sirasıyla \%76.1, \%89.3 ve $1386.1 \mu \mathrm{mol} \mathrm{Fe} \mathrm{II/g}$ olarak belirlenmiştir. ABTS radikali süpürücü aktivite ve DPPH radikali süpürücü aktivite sonuçlarının illere göre istatistiksel olarak önemli farklılıklar göstermediği belirlenmiştir. Morales ve ark. (2014) A.azurea bitkisi metil alkol ekstraktlarında DPPH aktivitesini $0.02 \mathrm{mg} / \mathrm{mL}$ olarak bulmuşlardır. Baghiani ve ark. (2013) A.azurea özütlerinin güçlü bir antioksidan aktivitesi olduğunu ve bu faaliyetlerin fenolik ve flavonoid içeriklerinden kaynaklandı ğ sonucuna varmışlardır. Marelli ve ark. (2015) ise yaptıkları çalışmada A.azurea bitkisinde antioksidan aktiviteyi $66.39 \mu \mathrm{g} / \mathrm{mL}$ olarak belirtmişlerdir.

\section{SONUÇ}

Bitkilerin biyokimyasal ve fizyolojik yapıları yetiştikleri ortamdaki ekolojik faktörlere göre değişmektedir. $\mathrm{Bu}$ çalışmada Elazığ ve Ardahan illerinden toplanan A.azurea Miller var. Azurea bitkisinin bazı biyoaktif bileşenlerinin miktarı ve antioksidan kapasiteleri karşılaştırılmıştır. Elazığ ilinden toplanan örneklerin toplam fenolik madde, toplam flavonoid madde ve askorbik asit içeriklerinin Ardahan örneklerine oranla daha yüksek olduğu belirlenmiştir. Klorofil $\mathrm{b}$ ve toplam karotenoid içerikleri ile DPPH radikali süpürücü aktivite değerleri ise Ardahan örneklerinde daha yüksek bulunmuştur. Yüksek biyoaktif bileşenleri, pigment içeriği ve antioksidan kapasitesi olan bu bitkiyle daha ileri düzeyde çalışmalar yapılması ve bitkinin tüketiminin artırılması gerekmektedir.

\section{KAYNAKLAR}

Anonim 2017. http://www.tubives.com/index.php? sayfa=1\&tax_id=6679, (Erişim Tarihi 23.10.2017).

AOAC 1990. Official methods of analysis of the Association of Official Analytical Chemists, 15th ed., Arlington VA, pp. 1058-1059.

Arı S 2014. Afyonkarahisar ve Civarında Halk Tarafından Kullanılan Bazı Bitkilerin Etnobotanik Özellikleri. AKÜ. Fen Bil. Ens., Biyoloji ABD, Doktora Tezi, $213 \mathrm{~s}$.

Aslantaş R, Karabulut H 2007. Rakımın Meyve Yetiştiriciliğinde Önemi ve Etkileri. Alınteri Zirai Bilimler Dergisi, 12: 31-37.

Baghiani A, Boumerfeg S, Boussoualim N, Trabsa H, Aouachria S, Arrar L 2013. In Vivo Free Radical Scavenging, Antihemolytic Activity and Antibacterial Effects of Anchusa azurea Extracts.
International Journal of Medicine and Medical Sciences, 46 (1): 1113-1118.

Benzie I F F, Strain J J 1996. The ferric reducing Ability of plasma (FRAB) as a measure of Antioxidant power: The FRAB assay. Analytical Biochemistry, 239: 70-76.

Boussoualim N, Trabsa H, Krache I, Arrar L, Khennouf S, Baghiani A 2014. Anti-bacterial and BLactamase inhibitory effects of Anchusa azurea and Globularia alypum extracts. Research Journal of Pharmaceutical, Biological and Chemical Sciences, 5(1): 742 .

Cemeroğlu B, Yemenicioğlu A, Özkan M 2001. Meyve ve Sebzelerin Bileşimi Soğukta Depolanmaları. Gıda Teknolojisi Derneği Yayınları, No: 24, Ankara.

Conforti F, Marrelli M, Carmela C, Menichini F, Valentina P, Uzunov D, Menichini F 2011. Bioactive phytonutrients (omega fatty acids, tocopherols, polyphenols), in vitro inhibition of nitric oxide production and free radical scavenging activity of non-cultivated Mediterranean vegetables. Food chemistry, 129(4): 1413-1419.

Cotton C M 1996. Ethnobotany Principles And Applications, John Wlley \& Sons, Chichester, 424s.

Çakılcıŏlu U, Türkoğlu İ, Kürşat M 2007. Harput (Elazığ) ve Çevresinin Etnobotanik Özellikleri, Doğu Anadolu Bölgesi Araştırmaları, 5: 22-28.

Çöteli E 2015. Investigation of Amounts of Vitamins A, E, C, Malondialdehyde and Glutathione in Plant $A$. azurea Miller var. Azurea. Adıyaman Üniversitesi Fen Bilimleri Dergisi, 5(2): 155-162.

Davis PH 1970. In: Davis PH (ed.) Flora of Turkey and the East Aegean Islands. Edinburgh: Edinburgh University Press, 3: 328-369.

De-Kok L, Graham M 1980. Levels of pigments, soluble proteins, amino acids and sulfhydryl compounds in foliar tissue of Arabidopsis thaliana during dark induced and natural senescence. Plant Physiology and Biochemistry, 27: 133-142.

Deniz L, Serteser A, Kargioğlu M 2011. Uşak Üniversitesi ve Yakın Çevresindeki Bazı Bitkilerin Mahalli Adları ve Etnobotanik Özellikleri. AKÜ Fen Bilimleri Dergisi, 13: 57-72.

Ertuğ F 2004. Etnobotanik Çalışmaları ve Türkiye'de Yeni Açılımlar. Kepikeç, 18: 181-187.

Galvis Sanchez AC, Gil-Izquierdo A, Gil MI 2003. Comparative study of six pear cultivars in terms of their phenolic and ascorbic acid contents and antioxidant capacity. Journal of the Science of Food and Agriculture, 83:995-1003.

Gelse A 2012. Adıyaman ve Çevresinin Etnobotanik Özellikleri, Yüzüncü Yıl Üniversitesi Fen Bilimleri Enstitüsü Biyoloji Anabilim Dalı, Yüksek Lisans Tezi, 214.

Gorinstein S, Martin-Belloso O, Lojek A, Cı́z M, Soliva-Fortuny R, Park YS, Caspi A, Libman I, Trakhtenberg S 2002. Comparative content of some phytochemicals in Spanish apples, peaches and 
pears. Journal of the Science of Food and Agriculture, 82:1166-1170.

Gökpınar Ş, Koray T, Akçiçek E, Göksan T, Durmaz Y 2006. Algal Antioksidanlar. E.Ü. Su Ürünleri Dergisi, 23:85-89.

Güner A, Özhatay N, Ekim T 2000. Flora of Turkey and the East Aegean Islands. Edinb. Univ. Press, Edinburg, 11s.

Halliwell B 2000. A super way to kill cancer cells? Nature Medicine, 6(10): 1105- 1106.

Koçyiğit M 2005. Yalova ilinde Etnobotanik Bir Araştırma, İ̈̈. Sağlık Bil. Ens., Farmösötik Botanik ABD, Yüksek Lisans Tezi, 65 s.

Korkutal İ, Bahar E, Özge K 2012. Rakımın Üzüm Kalitesi Üzerine Etkileri. Trakya Üniversitesi Mühendislik Bilimleri Dergisi, 13: 1729.

Kuruüzüm-Uz A, Güvenalp Z, Kazaz C, Demirezer LÖ 2013. Phenolic compounds From The Roots of Anchusa azurea var.azurea. Turkish Journal of Pharmaceutical Science, 10 (2): 177-184.

Li MF, Yao YY, Ding YL, Ge L, Cao XL, Li J, Yang DL 2017. Effect of altitude on fruit characteristics, bioactive compounds and antioxidant capacity in Podophyllum hexandrum. Acta Prataculturae Sinica, 26(4): 162-168.

Loranty A, Rembialkowska E, Rosa EAS, Bennett RN 2010. Identification, quantification and avaliability of carotenoids and chlorophylls in fruit, herb and medicinal teas. Journal of Food Composition and Analysis, 23: 432-441.

Macheix JJ, Fleuriet A, Billot J 1990. Fruit Phenolics. CRC Press, Boca Raton, Florida 46 p.

Marelli M, Cristaldi B, Menichini F, Conforti F 2015. Inhibitory effects of wild dietary plants on lipid peroxidation and on the proliferation of human cancer cells. Food and Chemical Toxicology. 86: 1614.

Martz F, Jaakola L, Julkunen-Tiitto R, Stark S 2010. Phenolic composition and antioxidant capacity of bilberry (Vaccinium myrtillus) leaves in northern Europe following foliar development and along environmental gradients. Journal of Chemical Ecology, 36(9): 1017-1028.

Mbaebie BO, Edeoga HO, Ajelayan AJ 2012. Phytochemical analysis and antioxidant activities of aqueous bark extract of Schoba lahtolic JACQ. Asian Pacific Journal of Tropical Biomedicine, 2: 118-124.

Morales P, Ferreira I, Carvalho A M, Sanchez-Mata C, Camara M, Fernandez-Ruiz V, Pardo-deSantayana M, Tardio J 2014. Mediterranean noncultivated vegetables as dietary sources of compounds with antioxidant and biological activity. LWT - Food Science and Technology, 55(1): 389-396. Murathan ZT 2017. Farklı Rakımlarda Yetişen Hippohae rhamnoides L. Meyvelerinin Antioksidan
Kapasiteleri ve Bazı Biyoaktif Özelliklerinin Incelenmesi. Erzincan University Journal of Science and Technology, 10(2): 20-27.

Murthy KB, Nammi S, Kota MK, Krishna Rao RV, Koteswara Rao N, Annapurna A 2004. Evaluation of hypoglycemic and antihyperglycemic effects of Datura metel (Linn.) seeds in normal and alloxaninduced diabetic rats. Journal of Ethnopharmacology, 9(1): 95-98.

Parejo L, Codina C, Petrakis C, Kefalas P 2000. Evaluation of scavenging activity assessed by Co(II)/EDTA-induced luminol chemiluminescence and DPPH center dot (2,2-diphenyl-1picrylhydrazyl) free radical assay. Journal of Pharmacological and Toxicological Methods, 44: 507-512.

Polat R, Satıl F 2012. An Ethnobotanical survey of medicinal plants in Edremit Gulf (BalıkesirTurkey). Journal of Ethnopharmacology, 39: 626641.

Quettier-Deleu C, Gressier B, Vasseur J, Dine T, Brunet J, Luyck M, Cazin M, Cazin JC, Bailleul F, Trotin F 2000. Phenolic compounds and antioxidant activities of buckwheat (Fagopyrum esculentum Moench) hulls and flour. Journal of Ethnopharmacology, 72: 35-40.

Re R, Pellegrini N, Proteggente A, Pannala A, Yang M, Rice-Evans C 1999. Antioxidant activity applying an improved ABTS radical cation decolorization assay. Free Radical Biology and Medicine, 26(9/10): 1231-1237.

Rezaeirad D, Bakhshi D, Ghasemnezhad M, Lahiji HS 2013. Evaluation of some quantitative and qualitative characteristics of local pears (Pyrus sp.) in the North of Iran. International Journal of Agriculture and Crop Sciences, 5(8): 882-887.

Rieger T 2007. Exploring High Altitude Viticulture, Part One. Vineyard \& Winery Management. 8490.

Spanos GA, Wrolstad RE 1992. Phenolic of apple, pear and white grape juices and their changes with processing and storage. Journal of Agricultural and Food Chemistry, 40(9):1478-1487.

Zengin G, Sarıkurkcu C, Aktümsek A, Ceylan O, Uysal S 2015. Screening of Possible In Vitro Neuroprotective, Skin Care, Antihyperglycemic, and Antioxidative Effects of Anchusa undulata L. subsp. hybrida(Ten.) Coutinho from Turkey and Its Fatty Acid Profile. International Journal of Food Properties, 18(7): 112.

Zilic S, Jankovic M, Basic Z, Vancetovic J, Maksimovic V 2016. Antioxidant activity, phenolic profile, chlorophyll and mineral matter content of corn silk (Zea mays L.): Comparison with medicinal herbs. Journal of Cereal Science, 69: 363-370. 